\title{
Complete mitochondrial genome sequence of Marmota himalayana (Rodentia: Sciuridae) and phylogenetic analysis within Rodentia
}

\author{
Q.J. Chao ${ }^{1 *}$, Y.D. Li ${ }^{2 *}$, X.X. Geng ${ }^{1}$, L. Zhang ${ }^{1}$, X. Dai ${ }^{1}$, X. Zhang ${ }^{1}$, \\ J. Li ${ }^{1}$ and H.J. Zhang ${ }^{1}$ \\ ${ }^{1}$ Department of Life Sciences, Huai Bei Normal University, Huaibei, China \\ ${ }^{2}$ School of Medicine, Qinghai University, Xining, China \\ *These two authors contributed equally to this study. \\ Corresponding author: X.X. Geng \\ E-mail: xuexiageng@163.com
}

Genet. Mol. Res. 13 (2): 2739-2751 (2014)

Received December 3, 2012

Accepted April 18, 2013

Published April 14, 2014

DOI http://dx.doi.org/10.4238/2014.April.14.3

\begin{abstract}
This is the first report of a complete mitochondrial genome sequence from Himalayan marmot (Marmota himalayana, class Marmota). We determined the M. himalayana mitochondrial (mt) genome sequence by using long-PCR methods and a primerwalking sequencing strategy with genus-specific primers. The complete mt genome of $M$. himalayana was 16,443 bp in length and comprised 13 protein-coding genes, 2 ribosomal RNA (rRNA) genes, 22 transfer RNA (tRNA) genes, and a typical control region (CR). Gene order and orientation were identical to those in $\mathrm{mt}$ genomes of most vertebrates. The heavy strand showed an overall $\mathrm{A}+\mathrm{T}$ content of $63.49 \%$. AT and GC skews for the $\mathrm{mt}$ genome of the $M$. himalayana were 0.012 and -0.300 , respectively, indicating a nucleotide bias against $\mathrm{T}$ and $\mathrm{G}$. The control region was $997 \mathrm{bp}$ in size and displayed some unusual features, including absence of repeated motifs and two conserved sequence blocks (CSB2 and
\end{abstract}


CSB3), which is consistent with observations from two other rodent species, Sciurus vulgaris and Myoxus glis. Phylogenetic analysis of complete mt DNA sequences without the control region including 30 taxa of Rodentia was performed with Maximum-Likelihood (ML) and Bayesian Inference (BI) methods and provided strong support for Sciurognathi polyphyly and Hystricognathi monophyly. This analysis also provided evidence that $M$. himalayana mt DNA was closely related to that from Sciurus vulgaris (Sciuridae) and was similar to mt DNA from Myoxus glis.

Key words: Marmota himalayana; Mitochondrial genome; Rodentia; Phylogenetic analysis

\section{INTRODUCTION}

Mitochondria are important subcellular organelles present in almost all animal tissue cells. They facilitate the reactions in the tricarboxylic acid cycle and electron transfer in oxidative phosphorylation, required for cellular energy generation. In organisms lacking chloroplasts, mitochondria are the only organelles besides the nucleus that have their own genomic DNA (Giles et al., 1980). The typical vertebrate mitochondrial (mt) genome is a closed circular DNA molecule with two strands (H-strand and L-strand), ranging 15-19 kb in size. The complete mtDNA contains a remarkably conserved set of 37 genes, including 13 protein-coding genes, 2 rRNA genes, and a full set of 22 tRNA genes (Wolstenholme, 1992; Boore, 1999). In addition, noncoding regions are mainly concentrated in a variable control region (CR) or D-loop with important functions in the regulation and initiation of mtDNA replication and transcription (Shadel and Clayton, 1993).

Marmots are large terrestrial rodents widespread across much of northern Eurasia and North America, including the Bering Strait region of western Alaska and eastern Siberia. Today, there are 14 recognized species of marmots throughout the world (Steppan et al., 1999). Among the four marmot species in China, Marmota himalayana is one of the species living at the highest altitudes in the region and has the widest distribution, covering parts of the Qinghai-Tibet Plateau and mountains, and meadows and grasslands in India, Nepal, and Pakistan. Marmot is an important animal with high economic value, and marmot products have a long history of development and use in China. To date, studies of M. himalayana have mainly focused on its ecology and ethology, and because of their close relationships with ground squirrels and prairie dogs, marmots have featured prominently in theories of social evolution in mammals (Barash, 1989; Arnold, 1990; Blumstein et al., 1997; Armitage, 1975, 1987, 1999). In recent years, helped by the development of long polymerase chain reaction (long-PCR) methods for amplification of mtDNA genes and complete $\mathrm{mt}$ genomes, comparative analyses of $\mathrm{mt}$ genome sequences and organizations are widely used to study phylogenetic relationships of animal taxa. The unique characters of mt DNA, such as its small size, simple structure, maternal inheritance, fast evolutionary rate, and high informational content, have made mt DNA a very attractive subject of research (Miyata et al., 1982; Brown, 1983; Moritz et al., 1987; Wolstenholme, 1992; Avis, 1994; Castro et al., 1998; Saccone et al., 1999; Yamanoue et 
al., 2007; Zhou et al., 2009). More than 1200 complete $\mathrm{mt}$ genome sequences are currently available in GenBank, including $\mathrm{mt}$ sequences from various vertebrate groups. Although some studies have investigated mitochondrial genes from M. himalayana, such as the Cytb gene (Steppan et al., 1999), no complete mt genome of the 14 species of marmots has yet been reported, and only one complete $\mathrm{mt}$ genome from Sciuridae (Sciurus vulgaris, accession No. AJ238588) is available in GenBank (Reyes et al., 2000). Likewise, previous studies of Rodentia phylogenies have mainly focused on rodent positions within mammalian phylogenetic trees (Reyes et al.,1998, 2000, 2004; Kjer and Honeycutt, 2007; David et al., 2007).

In this study, we describe for the first time the complete mt genome of M. himalayana and discuss phylogenetic relationships within Rodentia. This provides an important resource for comparative analyses of the evolution of mitochondrial genomes in rodents.

\section{MATERIAL AND METHODS}

\section{Sample collection and DNA extraction}

Tissue samples were preserved at $-20^{\circ} \mathrm{C}$ until analysis. Total genomic DNA in samples was extracted by a phenol/chloroform/isoamylalcohol method.

\section{PCR amplification and sequencing}

To obtain the complete sequence of the $\mathrm{mt}$ genome, seven pairs of primers were designed by using NCBI primer-BLAST (http:/www.ncbi.nlm.nih.gov/tools/primerblast/) on the basis of alignments and comparisons of the genome sequence of Sciurus vulgaris and partial sequences of the $M$. himalayana $\mathrm{mt}$ genome (Table 1). The long polymerase chain reaction (long-PCR) technique was carried out to amplify the complete $M$. himalayana mt genome. PCR was performed in $50-\mu \mathrm{L}$ volume containing $5 \mu \mathrm{L} 10$ X LA PCR buffer II (TaKaRa), $8 \mu \mathrm{L} 4 \mathrm{mM}$ dNTP, $2 \mu \mathrm{L} 10 \mu \mathrm{M}$ of each primer, $2 \mu \mathrm{L} 1 \mathrm{mM} \mathrm{MgCl}$, $0.5 \mu \mathrm{L} 2.5 \mathrm{U}$ LA Taq polymerase, and $1 \mu \mathrm{L}$ genomic DNA. PCR cycling conditions were the following: initial denaturation step of $5 \mathrm{~min}$ at $94^{\circ} \mathrm{C}$, followed by 35 cycles of $1 \mathrm{~min}$ at $94^{\circ} \mathrm{C}, 1 \mathrm{~min}$ at $58^{\circ} \mathrm{C}$, and $2-5 \mathrm{~min}$ at $72^{\circ} \mathrm{C}$, and a final extension step at $72^{\circ} \mathrm{C}$ for 10 min. The resultant PCR products were checked by electrophoresis on a $1.0 \%$ agarose gel (Promega, Madison, WI, USA), staining with ethidium bromide, and visualization under UV on a transilluminator, followed by purification with PCR Purification Kit (Qiagen, USA). Two microliter of the purified PCR products were electrophoresed again to determine DNA concentrations by visual comparison of DNA band intensities with intensities of DNA size standards run alongside. The purified products were directly sequenced in both directions on an ABI 3730 XL Sequencer by using the primer walking method with the species-specific primers.

\section{Sequence analysis}

Editing and assembly of the mitochondrial sequences were performed with the DNAStar 7.1 software and program CLUSTAL_W 2.1 (Thompson et al., 1997). The inte- 
grated mt genome sequence has been deposited in GenBank by the Sequin software (http:// www.ncbi.nlm.nih.gov/sequin/index.html) under accession No. JX069958. The 13 proteincoding genes and 2 rRNA genes were identified by DOGMA (Wyman et al., 2004) and their similarity to published gene sequences in NCBI identified by BLAST searches (http:// www.ncbi.nlm.nih.gov/BLAST/). The tRNA genes were identified by tRNA Scan-SE version 1.21 (http://lowelab.ucsc.edu/tRNAscan-SE/) (Lowe and Eddy, 1997). The remaining $t R N A^{\operatorname{Ser}(G C U)}$ gene was not found by tRNAscan-SE and was therefore predicted using its anticodons with the RNAstructure 4.5 and the RNAdraw software (Mathews et al., 1999, 2004). The CR region was identified by sequence homology and proposed secondary structures. Composition skew analysis of AT and the GC bases was conducted to find nucleotide bases that were different among the $\mathrm{mt}$ genomes of $M$. himalayana and other species of the Marmota genus. Codon usage was calculated by CodonW version 1.3 (http://bioweb.pasteur. $\mathrm{fr} /$ seqanal/codonw.html). Tandem repeats of the whole sequence were tested by Tandem Repeats Finder (Benson, 1999).

\begin{tabular}{|c|c|c|c|}
\hline Order & Primer name & Sequence $\left(5^{\prime}-3^{\prime}\right)$ & Product size (bp) \\
\hline \multirow[t]{2}{*}{1} & ND4F & TGCTGGTTCTATAGTTTTAGCCGCC & 3330 \\
\hline & CYR & AGAGGGTGGGTTTTGCGGGTG & \\
\hline \multirow[t]{2}{*}{2} & Mt76 & ACGATCCATCCCCAACAAACTAGGA & 3124 \\
\hline & $16 \mathrm{RR}$ & TGGCTGCTTTTAGGCCAACTATGGA & \\
\hline \multirow[t]{2}{*}{3} & ND3F & CCCATAGGATCTGCTCGCTTACCA & 1007 \\
\hline & ND4R & ACCGTTCAGTTTGGTTTCCCCATCG & \\
\hline \multirow[t]{2}{*}{4} & ND4LF & TTGCCGCATGTGAAGCAGCTGTA & 1216 \\
\hline & ND4 & GTTAATGGAGGGTGGAAGGGCTAGA & \\
\hline \multirow[t]{2}{*}{5} & ValF & ACCCGGCTTACACCCGAGAG & 8668 \\
\hline & NDCR & GTTTGGGAAGCTCAGGGAAGAGGGA & \\
\hline \multirow[t]{2}{*}{6} & ND4F & AGCCCACGTCGAAGCTCCCAT & 2842 \\
\hline & ND6R & TGAAGATTCAATAGGGGTGGCGGC & \\
\hline \multirow[t]{2}{*}{7} & ND6 & GCTTTGAAGAAACCCCCACAAAGCC & 3199 \\
\hline & $12 \mathrm{RF}$ & CCACCCTATAGGCTACACCTTGACC & \\
\hline
\end{tabular}

\section{Phylogenetic analyses}

The phylogenetic analyses were performed on the complete mt DNA sequences of $M$. himalayana (this study) and from 29 Glires species retrieved from GenBank (Table 2). Lepus europaeus, Oryctolagus cuniculus, and Ochotona princeps from the family Lagomorpha were used as outgroups. The nucleotide sequences of 30 complete mt genome - with the control region excluded - were used in the phylogenetic analysis as follows: First, the sequence alignment and a site-specific rate model were constructed according to Kjer et al. (Kjer et al., 2001; Kjer and Honeycutt, 2007). Two different phylogenetic reconstruction approaches including Maximum Likelihood (ML) and Bayesian Inference (BI) were used to reconstruct phylogenetic trees. For ML analysis, 100 bootstraps were performed to estimate the node support with RaxML-7.04 (Stamatakis, 2006). Bayesian analysis was conducted by MrBayes 3.1.2 (Ronquist and Huelsenbeck, 2003) under the GTR + gamma model, and the Markov chain Monte Carlo (MCMC) chains were run for 10,000,000 generations (sampling every 1000 generations) to allow adequate time for convergence. Discarding the first 1000 trees as burn-in, the remaining trees were used to estimate posterior probabilities. 
Table 2. List of mitochondrial genomes analyzed in this study.

\begin{tabular}{|c|c|c|}
\hline Species & Classification & Accession No. \\
\hline Neodon irene & Glires; Rodentia; Sciurognathi; Muroidea; Cricetidae & NC_016055.1 \\
\hline Microtus kikuchii & Glires; Rodentia; Sciurognathi; Muroidea; Cricetidae & AF348082.1 \\
\hline Proedromys liangshanensis & Glires; Rodentia; Sciurognathi; Muroidea; Cricetidae & NC_013563.1 \\
\hline Eothenomys chinensis & Glires; Rodentia; Sciurognathi; Muroidea; Cricetidae & NC_013571.1 \\
\hline Cricetulus griseus & Glires; Rodentia; Sciurognathi; Muroidea; Cricetidae & NC_007936.1 \\
\hline Tscherskia triton & Glires; Rodentia; Sciurognathi; Muroidea; Cricetidae & NC_013068.1 \\
\hline Mesocricetus auratus & Glires; Rodentia; Sciurognathi; Muroidea; Cricetidae & EU660218.1 \\
\hline Mus musculus & Glires; Rodentia; Sciurognathi; Muroidea; Muridae & NC_005089.1 \\
\hline Apodemus chejuensis & Glires; Rodentia; Sciurognathi; Muroidea; Muridae & NC_016662.1 \\
\hline Rattus norvegicus & Glires; Rodentia; Sciurognathi; Muroidea; Muridae & AJ428514.1 \\
\hline Nannospalax ehrenberg & Glires; Rodentia; Sciurognathi; Muroidea; Spalacidae & NC_005315.1 \\
\hline Spalax ehrenbergi & Glires; Rodentia; Sciurognathi; Muroidea; Spalacidae & AJ416891.1 \\
\hline Eospalax baileyi & Glires; Rodentia; Sciurognathi; Muroidea; Spalacidae & NC 018098.1 \\
\hline Sciurus vulgaris & Glires; Rodentia; Sciurognathi; Sciuridae; Sciurinae & NC_002369.1 \\
\hline Marmota himalayana & Glires; Rodentia; Sciurognathi; Sciuridae; Xerinae & NC_018367.1 \\
\hline Jaculus & Glires; Rodentia; Sciurognathi; Dipodidae; Dipodinae & NC_005314.1 \\
\hline Myoxus glis & Glires; Rodentia; Sciurognathi; Gliridae; Glirinae & NC_001892.1 \\
\hline Castor Canadensis & Glires; Rodentia; Sciurognathi; Castoridae; Castor & NC_015108.1 \\
\hline Anomalurus & Glires; Rodentia; Sciurognathi; Anomaluridae; Anomalurus & NC_009056.1 \\
\hline Octodon degus & Glires; Rodentia; Hystricognathi; Octodontidae; Octodon & HM544134.1 \\
\hline Spalacopus cyanus & Glires; Rodentia; Hystricognathi; Octodontidae; Spalacopus & HM544133.1 \\
\hline Tympanoctomys barrerae & Glires; Rodentia; Hystricognathi; Octodontidae; Tympanoctomys & HM544132.1 \\
\hline Ctenomys leucodon & Glires; Rodentia; Hystricognathi; Ctenomyidae; Ctenomys & HM544131.1 \\
\hline Proechimys longicaudatus & Glires; Rodentia; Hystricognathi; Echimyidae; Proechimys & HM544128.1 \\
\hline Cavia porcellus & Glires; Rodentia; Hystricognathi; Caviidae; Cavia & AJ 222767 \\
\hline Thryonomys swinderianus & Glires; Rodentia; Hystricognathi; Thryonomyidae; Thryonomys & NC_002658.1 \\
\hline Heterocephalus glaber & Glires; Rodentia; Hystricognathi; Bathyergidae; Heterocephalus & NC_015112.1 \\
\hline Lepus europaeus & Glires; Lagomorpha; Leporidae; Lepus & AJ421471 \\
\hline Oryctolagus cuniculus & Glires; Lagomorpha; Leporidae; Oryctolagus & AJ001588 \\
\hline Ochotona princeps & Glires; Lagomorpha; Leporidae; Oryctolagus & AJ537415 \\
\hline
\end{tabular}

\section{RESULTS}

\section{Genome organization and features}

The mitochondrial DNA sequence of Marmota himalayana was identified as a circular molecule of 16,443 bp consisting of 2 rRNAs ( $r r R N A$ and $\operatorname{lr} R N A$ ), 13 PCGs, 22 tRNAs, and a control region (CR). The three different types of genes and their numbers were the same as previously identified in most vertebrate $\mathrm{mt}$ genomes. Among the 37 genes identified, 8 tRNA genes and the ND6 gene were encoded on the L-strand, and the remaining 28 genes were encoded on the $\mathrm{H}$-strand. The arrangement of the genes in the $M$. himalayana $\mathrm{mt}$ genome is summarized in Figure 1 and Table 3 . The complete $\mathrm{mt}$ genome of Marmota himalayana is somewhat shorter than that of the Sciuridae species Sciurus vulgaris $(16,507 \mathrm{bp})$. This size variation mainly resulted from differences in the length of the control region among the Rodentia species; therefore, when the CR region was excluded, the mt genome sequences of the Rodentia species were nearly identical in length. In addition, similar to the $\mathrm{mt}$ genomes in most vertebrates, overlaps and similar intervals were observed for several genes in the Marmota himalayana mt genome, with the most typical interval extending up to 30 nucleotides between the $t R N A^{A s n}$ and $t R N A^{C y s}$ genes. 


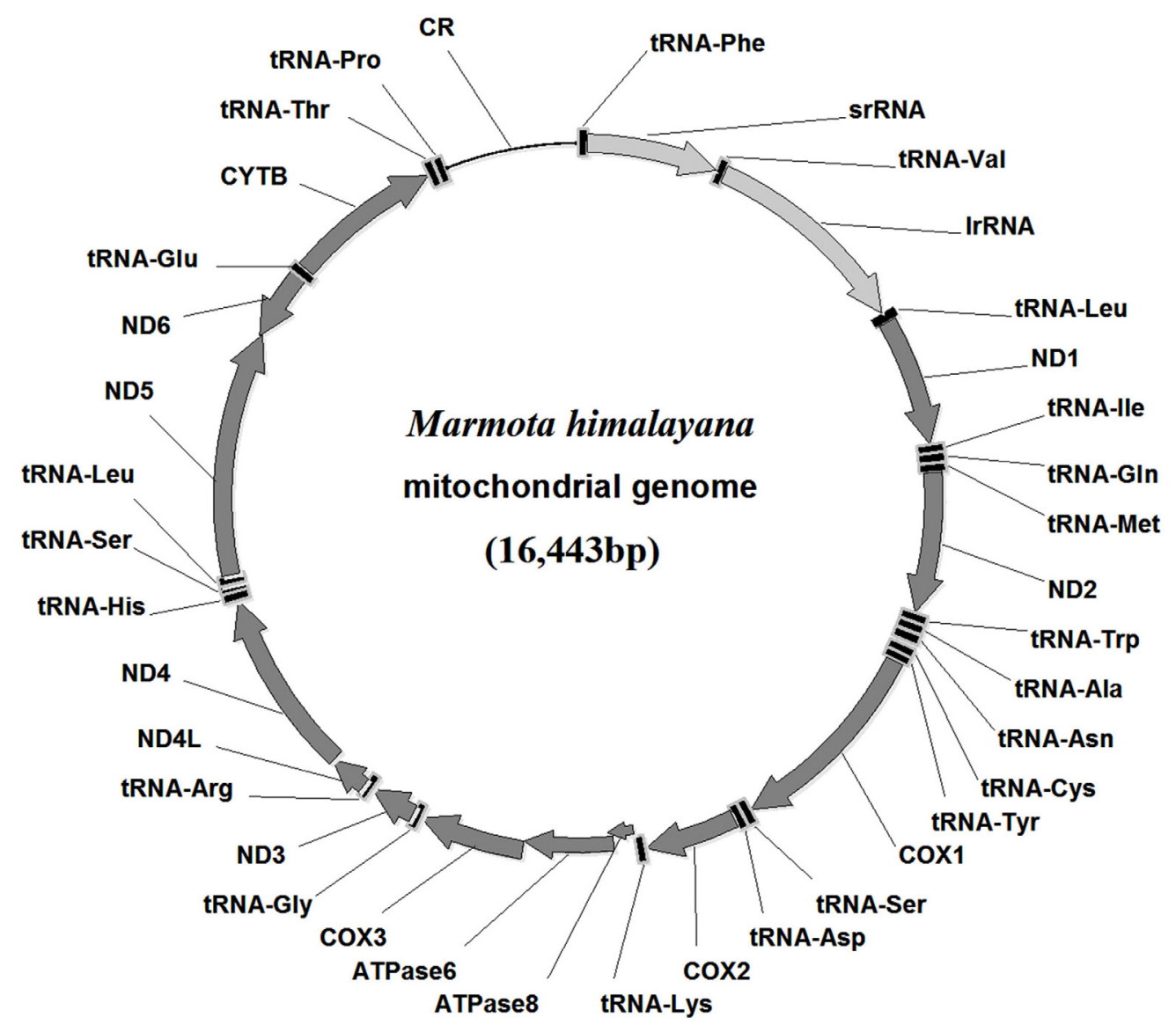

Figure 1. Gene map of the Marmota himalayana mtDNA. Protein-coding genes (deep-gray) and rRNA genes (light-gray) are identified by arrows. The ND6 gene is transcribed in the opposite direction as relative to the rest PCGs. tRNA genes (black) are depicted with their corresponding amino acids.

\section{Nucleotide composition and base bias}

The total nucleotide base composition of the M. himalayana mt genome was A (32.13\%) $>\mathrm{T}(31.36 \%)>\mathrm{C}(23.73 \%)>\mathrm{G}(12.78 \%)$ (Table 4). Its overall A+T content was $63.49 \%$, which is similar to that in the $\mathrm{mt}$ genome of Sciurus vulgaris (62.97\%). To investigate potential base bias, we calculated the AT and GC skews for the M. himalayana mt genome, including CR, proteincoding, and ribosomal RNA genes, and identified an AT skew of 0.012 and a GC skew of -0.300 . We also noted that all GC skews and most of the AT skews were negative for the protein-coding genes, indicating that $\mathrm{C}$ and $\mathrm{T}$ residues were more prevalent than $\mathrm{G}$ and $\mathrm{A}$ residues in these genes, which is consistent with previous observations that vertebrate sequences have a bias against the use of G (Saccone et al., 1999). The nucleotide compositions in the rRNA genes (63.2\% AT) and in the CR $(62.2 \% \mathrm{AT})$ were similar to compositions in the complete $\mathrm{mt}$ genome, and, therefore, an $\mathrm{A}+\mathrm{T}$ bias pattern holds for all functional segments of the M. himalayana mt genome. 
Table 3. Organization of Marmota himalayan mitochondrial genome.

\begin{tabular}{|c|c|c|c|c|c|c|c|}
\hline Gene & From & To & Size (bp) & Start codon & Stop codon & Strand & Amino acid \\
\hline$t R N A^{\text {Phe }}$ & 1 & 69 & 69 & & & $\mathrm{H}$ & $\mathrm{F}$ \\
\hline $\operatorname{srRNA}$ & 70 & 1040 & 971 & & & $\mathrm{H}$ & \\
\hline$t R N A^{V a l}$ & 1041 & 1109 & 69 & & & $\mathrm{H}$ & $\mathrm{V}$ \\
\hline $\operatorname{lr} R N A$ & 1110 & 2677 & 1568 & & & $\mathrm{H}$ & \\
\hline$t R N A^{\operatorname{Leu}(U A A)}$ & 2678 & 2751 & 74 & & & $\mathrm{H}$ & $\mathrm{L}$ \\
\hline$N D 1$ & 2755 & 3710 & 956 & ATG & TA- & $\mathrm{H}$ & +3 \\
\hline$t R N A^{I l e}$ & 3711 & 3779 & 69 & & & $\mathrm{H}$ & I \\
\hline$t R N A^{G l n}$ & 3777 & 3848 & 72 & & & $\mathrm{~L}$ & Q -3 \\
\hline$t R N A^{M e t}$ & 3852 & 3920 & 69 & & & $\mathrm{H}$ & $\mathrm{M}+3$ \\
\hline$N D 2$ & 3921 & 4962 & 1042 & ATT & T-- & $\mathrm{H}$ & \\
\hline$t R N A^{T r p}$ & 4963 & 5030 & 68 & & & $\mathrm{H}$ & W \\
\hline$t R N A^{A l a}$ & 5034 & 5102 & 70 & & & $\mathrm{~L}$ & $\mathrm{~A}+3$ \\
\hline$t R N A^{A s n}$ & 5108 & 5180 & 73 & & & $\mathrm{~L}$ & $\mathrm{~N}+5$ \\
\hline$t R N A^{C y s}$ & 5211 & 5277 & 67 & & & $\mathrm{~L}$ & $\mathrm{C}+30$ \\
\hline$t R N A^{T_{y} r}$ & 5278 & 5343 & 66 & & & $\mathrm{~L}$ & $\mathrm{Y}$ \\
\hline $\mathrm{COI}$ & 5352 & 6893 & 1545 & ATG & TAG & $\mathrm{H}$ & +8 \\
\hline$t R N A^{\operatorname{Ser}(U G \mathrm{~A})}$ & 6896 & 6964 & 69 & & & $\mathrm{~L}$ & $\mathrm{~S}+2$ \\
\hline$t R N A^{A s p}$ & 6968 & 7036 & 69 & & & $\mathrm{H}$ & $\mathrm{D}+3$ \\
\hline $\mathrm{CO} 2$ & 7037 & 7720 & 684 & ATG & TAA & $\mathrm{H}$ & \\
\hline$t R N A^{L y s}$ & 7724 & 7790 & 67 & & & $\mathrm{H}$ & $\mathrm{K}+3$ \\
\hline ATPase 8 & 7792 & 7995 & 204 & ATG & TAG & $\mathrm{H}$ & +1 \\
\hline ATPase 6 & 7953 & 8632 & 680 & ATG & TT- & $\mathrm{H}$ & -3 \\
\hline $\mathrm{CO} 3$ & 8633 & 9416 & 784 & ATG & T-- & $\mathrm{H}$ & \\
\hline$t R N A^{G l y}$ & 9417 & 9486 & 70 & & & $\mathrm{H}$ & G \\
\hline$N D 3$ & 9487 & 9833 & 347 & ATA & TA- & $\mathrm{H}$ & \\
\hline$t R N A^{A r g}$ & 9834 & 9900 & 67 & & & $\mathrm{H}$ & $\mathrm{R}$ \\
\hline$N D 4 L$ & 9902 & 10198 & 297 & ATG & TAA & $\mathrm{H}$ & +1 \\
\hline ND4 & 10192 & 11569 & 1378 & ATG & T-- & $\mathrm{H}$ & +7 \\
\hline$t R N A^{H i \mathrm{~s}}$ & 11570 & 11638 & 69 & & & $\mathrm{H}$ & $\mathrm{H}$ \\
\hline$t R N A^{\operatorname{Ser}(G C U)}$ & 11640 & 11696 & 57 & & & $\mathrm{H}$ & $\mathrm{S}+1$ \\
\hline$t R N A^{\operatorname{Leu}(U A G)}$ & 11698 & 11767 & 70 & & & $\mathrm{H}$ & $\mathrm{L}+1$ \\
\hline ND5 & 11768 & 13585 & 1818 & ATT & TAA & $\mathrm{H}$ & \\
\hline ND6 & 13569 & 14093 & 525 & ATG & AGA & $\mathrm{L}$ & -17 \\
\hline$t R N A^{G l u}$ & 14094 & 14162 & 69 & & & $\mathrm{~L}$ & $\mathrm{E}$ \\
\hline CYTB & 14167 & 15306 & 1140 & ATG & AGA & $\mathrm{H}$ & +3 \\
\hline$t R N A^{T h r}$ & 15307 & 15373 & 67 & & & $\mathrm{H}$ & $\mathrm{T}$ \\
\hline$t R N A^{P r o}$ & 15379 & 15446 & 68 & & & $\mathrm{~L}$ & $\mathrm{P}+4$ \\
\hline CR & 15447 & 16443 & 997 & & & $\mathrm{H}$ & +997 \\
\hline
\end{tabular}

Table 4. Nucleotide composition and skews of Marmota himalayana mitochondrial protein-coding and ribosomal RNA genes.

\begin{tabular}{|c|c|c|c|c|c|c|c|}
\hline \multirow[t]{2}{*}{ Gene } & \multicolumn{4}{|c|}{ Proportion of nucleotides } & \multirow[t]{2}{*}{$\% \mathrm{AT}$} & \multirow[t]{2}{*}{ AT skew } & \multirow[t]{2}{*}{ GC skew } \\
\hline & $\mathrm{A}$ & $\mathrm{T}$ & $\mathrm{G}$ & $\mathrm{C}$ & & & \\
\hline ND1 & 31.0 & 32.6 & 11.0 & 25.4 & 63.6 & -0.025 & -0.396 \\
\hline ND2 & 34.3 & 30.7 & 8.6 & 26.4 & 65.0 & 0.055 & -0.509 \\
\hline $\mathrm{COl}$ & 27.9 & 34.2 & 16.3 & 21.6 & 62.1 & -0.102 & -0.140 \\
\hline $\mathrm{CO} 2$ & 32.8 & 30.4 & 13.2 & 23.7 & 63.2 & 0.038 & -0.285 \\
\hline ATPase8 & 35.3 & 32.4 & 7.8 & 24.5 & 67.7 & 0.043 & -0.517 \\
\hline ATPase6 & 30.2 & 33.1 & 10.7 & 26.0 & 63.3 & -0.046 & -0.417 \\
\hline $\mathrm{CO} 3$ & 27.3 & 32.1 & 15.1 & 25.5 & 59.4 & -0.081 & -0.256 \\
\hline ND3 & 27.7 & 36.0 & 12.7 & 23.6 & 63.7 & -0.130 & -0.300 \\
\hline$N D 4 L$ & 28.0 & 37.4 & 11.4 & 23.2 & 65.4 & -0.144 & -0.341 \\
\hline ND4 & 31.5 & 34.0 & 10.0 & 24.5 & 65.5 & -0.038 & -0.420 \\
\hline ND5 & 31.3 & 33.0 & 10.0 & 25.7 & 64.3 & -0.026 & -0.440 \\
\hline ND6 & 39.8 & 23.6 & 7.3 & 29.3 & 63.4 & 0.256 & -0.601 \\
\hline CYTB & 28.9 & 32.9 & 12.5 & 25.7 & 61.8 & -0.065 & -0.346 \\
\hline $\operatorname{srRNA}$ & 35.8 & 25.4 & 17.1 & 21.7 & 61.2 & 0.170 & -0.119 \\
\hline $\operatorname{lr} R N A$ & 37.0 & 27.4 & 16.6 & 19.0 & 64.4 & 0.150 & -0.067 \\
\hline $\mathrm{CR}$ & 30.3 & 31.9 & 12.9 & 24.9 & 62.2 & -0.026 & -0.317 \\
\hline Mitochondrial genome & 32.1 & 31.4 & 12.8 & 23.7 & 63.5 & 0.011 & -0.299 \\
\hline
\end{tabular}

Genetics and Molecular Research 13 (2): 2739-2751 (2014) 


\section{Protein-coding genes}

The complete mtDNA of $M$. himalayana encodes 13 protein-coding genes (PCGs). The arrangement and directions of all 13 PCGs are the same as observed in other vertebrate $\mathrm{mt}$ genomes (Figure 1). Among the 13 PCGs, ND2 and ND5 use ATT as start codon, whereas ND5 appears to use ATT instead of the canonical ATG start codon. As shown in Table 3, the other 10 PCGs had the standard ATG start codon. TAA as a stop codon was observed in $\mathrm{CO}$, $N D 4 L$, and ND5, whereas TAG was the stop codon in CO1 and ATPase8. AGA was observed as the stop codon in ND6 and $C Y T B$, while the remaining 6 PCGs were apparently terminated by an incomplete stop codon, TA_ (ND1, ND3), TT_ (ATPase6), or T_ (ND2, CO3, ND4), thus differing from the typical stop codons found in PCGs (TAA, TAG, TGA). Incomplete stop codons commonly exist in vertebrate mt genomes, and these incomplete codons are typically restored to functional stop codons by posttranscriptional polyadenylation during mRNA maturation (Ojala et al., 1981).

Some of the 13 PCGs displayed sequence overlaps: for instance, the ATPase 8 and ATPase 6 overlapped by a 43-bp long sequence, and ND4 and ND4L shared a seven-nucleotide overlap. Such gene overlaps are found in many vertebrate mtDNAs.

\section{Ribosomal and transfer RNA genes}

Small and large ribosomal RNA genes ( $s r R N A$ and $\operatorname{lr} R N A$ ) were 70 and 1110-bp long, respectively, and appeared to be transcribed from the H-strand of the M. himalayana mt genome. The rRNA genes were located between $t R N A^{\text {Phe }}$ and $t R N A^{\operatorname{Len}(U A A)}$ and separated by the gene for $t R N A^{\text {Val }}$, as observed for other vertebrate mt genomes (Delisle and Strobeck, 2002; Hwang et al., 2008).

Twenty-two tRNA genes, ranging 57-74 bp in size and scattered throughout the mt genome, were identified in M. himalayana. Of these, 21 were identified by tRNAscan, identified by typical cloverleaf secondary structures with normal base pairing and harboring anticodons that match the vertebrate mitochondrial genetic code (Figure 2). The remaining $t R N A^{\operatorname{Ser}(G C U)}$ gene was $57 \mathrm{bp}$ in size determined by visual inspection and comparison with the Sciurus vulgaris $\mathrm{mt}$ genome sequence. Unlike the other $21 \mathrm{tRNA}$ genes, the $t R N A^{\operatorname{Ser}(G C U)}$ gene cannot form a typical cloverleaf structure because it lacks the appropriate sequence to form the dihydrouridine arm and loop. This unusual secondary structure is also found in many mt genomes from other vertebrates, including bear, coyote, dogs, Eurasian otter, and wild camel (Peng et al., 2007; Hou et al., 2007; Cui et al., 2007; Hwang et al., 2008). Mismatches were observed in the amino acid-acceptor arms, anticodon, and T $\psi \mathrm{C}$ stems of some $M$. himalayana tRNA genes $\left[t R N A^{\text {Phe }}, \mathrm{t} R N A^{V a l}, t R N A^{\text {Met }}, t R N A^{G l y}, t R N A^{\text {Leu(UAG)}}\right]$, which may be restored through RNA-editing mechanisms.

\section{Non-coding regions}

A total of $1075 \mathrm{bp}$ in the $M$. himalayana $\mathrm{mt}$ genome corresponded to non-coding sequences, spread over 15 intergenic segments and ranging 1-997 bp in size. The largest (997 bp) non-coding region, CR, was identified between the $t R N A^{\text {Pro }}$ and $t R N A^{\text {Phe }}$ genes, with an $\mathrm{A}+\mathrm{T}$ content of $62.2 \%$. By comparing the complete CR region in M. himalayana with the corre- 
sponding CRs in other mammalians (Sbisa et al., 1997, Cui et al., 2007; Hwang et al., 2008), we could compartmentalize the $\mathrm{CR}$ of $M$. himalayana into three domains: domain (D)-I, -II, and -III (Figure 3), corresponding to the termination-associated sequence domain (TAS), the central conserved domain (CD), and the conserved sequence block domain (CSB) (Sbisa E, 1997). We found a termination-associated sequence (TAS-A) and six conserved sequence blocks (CSB1 and $\mathrm{B}-\mathrm{F})$, which contain regulatory sequences controlling replication and transcription. Among Sciuridae animals, the TAS-A, CSB1, and CSBB-F are highly conserved; however, CSB2 and CSB3 are absent from some of them. In addition, we found no repetitive motifs in the CR of the M. himalayana, which is identical with that of the Sciurus vulgaris and Myoxus glis.

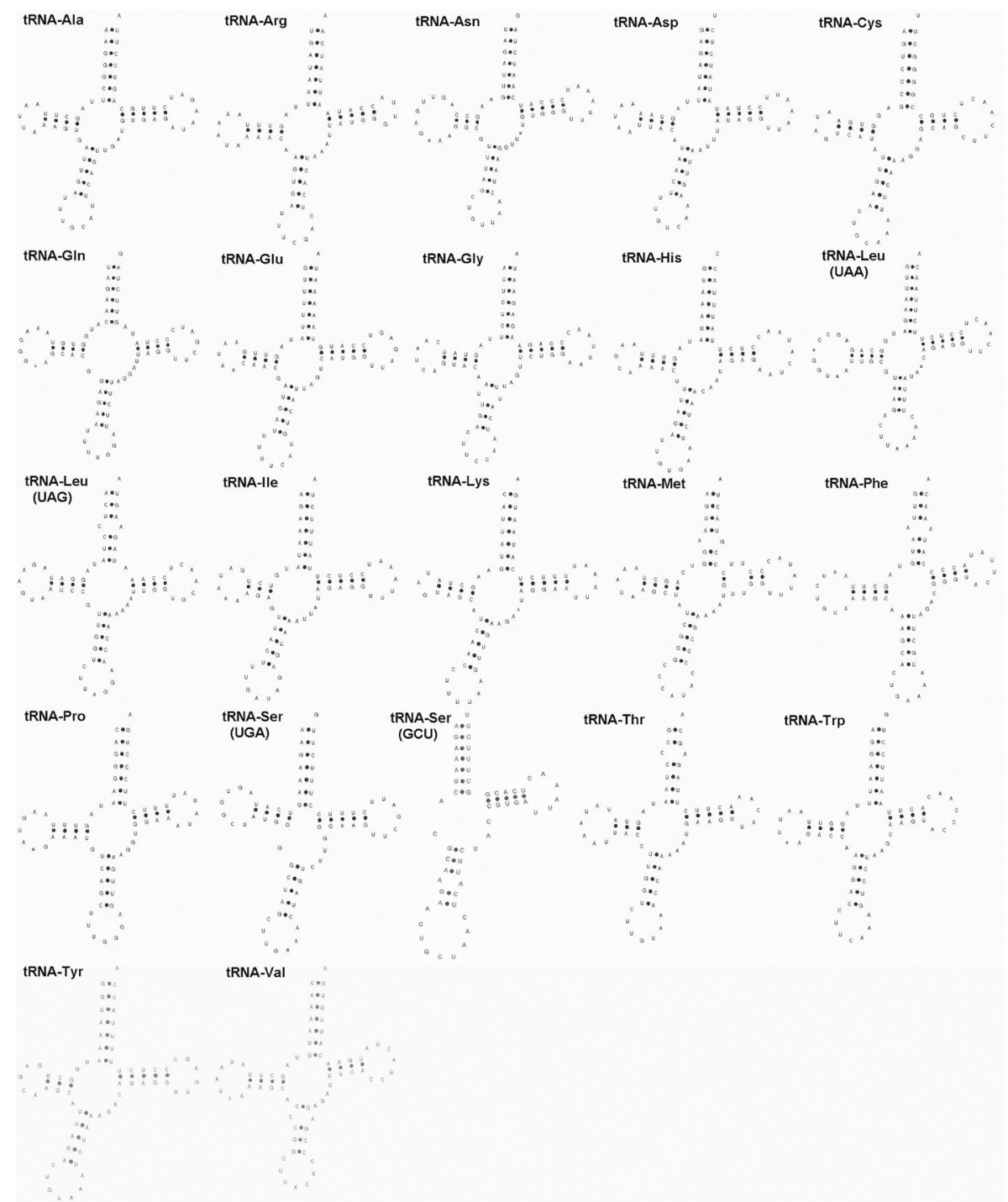

Figure 2. Putative secondary structures of 22 mitochondrial tRNAs from the Marmota himalayana. 


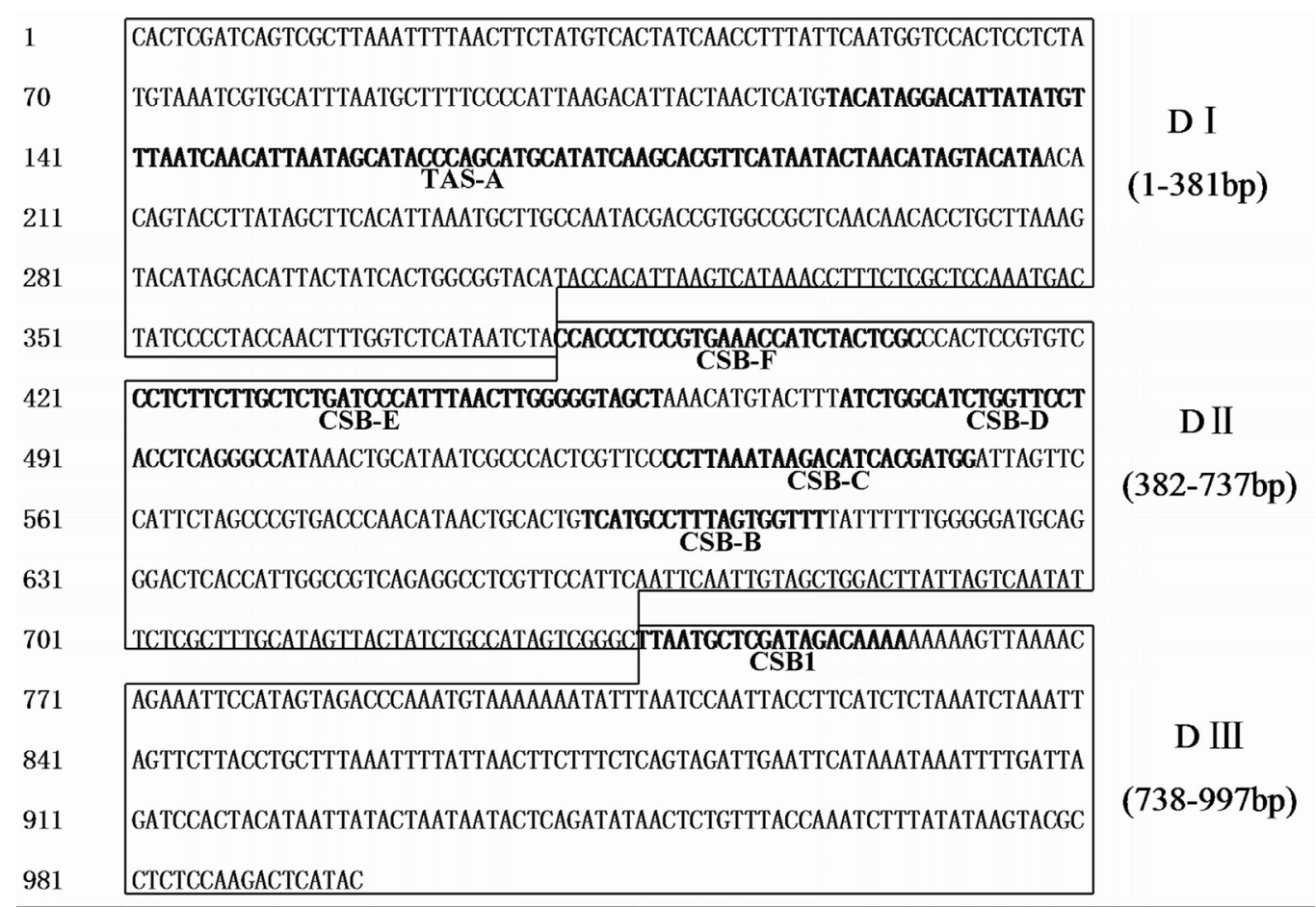

Figure 3. Organization of the Marmota himalayana control region. The control region consists of the extended termination-associated sequence (TAS-A: in DI), and the central conserved (CSB-B, C, D, E, F: in DII) and conserved sequence block (CSB1; in DIII) domains.

\section{Phylogenetic relationships within Rodentia}

Tree topologies obtained by ML and BI analyses were almost identical (Figure 4). The phylogenetic tree supports Sciurognathi polyphyly and Hystricognathi monophyly. M. himalayana clustered with $S$. vulgaris representing Sciuridae with high statistical support (100\% $\mathrm{BP}$ under ML and $1.00 \mathrm{PP}$ under Bayesian analysis $)$ and then M. glis $(\mathrm{BP}=100 \%, \mathrm{PP}=1.00)$ formed a basal clade to the Sciurognathi in accordance with morphological and paleontological surveys, providing evidence for the close relationship between Gliridae and Sciuridae. The Hystricognathi taxa formed a highly supported monophyletic clade (100\% BP and $1.00 \mathrm{PP})$, and formed a sister group to the Anomaluridae/Castoridae clade, with lower support (92\% BP and $0.69 \mathrm{PP}$ ). In addition, both analyses strongly supported the monophyly of the Muroidea/ Dipodidae grouping (all with PP $=1.00$ ), and Dipodidae was found at the base of the Muroidea clade with $100 \%$ support and assumed to be basal in Muroidea. This observation was identical to a previous finding based on amino acid analysis of the 12 PCGs located on the H-strand (David et al., 2007). Our observations differed from those in some previous studies (Reyes et al., 2004; Kjer and Honeycutt, 2007; David et al., 2007) in that the Hystricognathi with Anomaluridae/Castoridae group was identified as a sister clade to the Muroidea/Dipodidae group with high statistical support $(\mathrm{BP}=97 \%, \mathrm{PP}=0.99$ ), but the Myoxidae/Sciuridae clade was at the base of these two groups, not being a sister clade to the Muroidea/Dipodidae group. The 
M. himalayana sequence may have been responsible for this discrepancy, since its inclusion tended to cluster the Myoxidae/Sciuridae clade with the outgroup. However, the statistical support for the internal nodes of these clades was strong (92-100 BP and 0.69-1.00 PP) in both ML tree and BI trees.

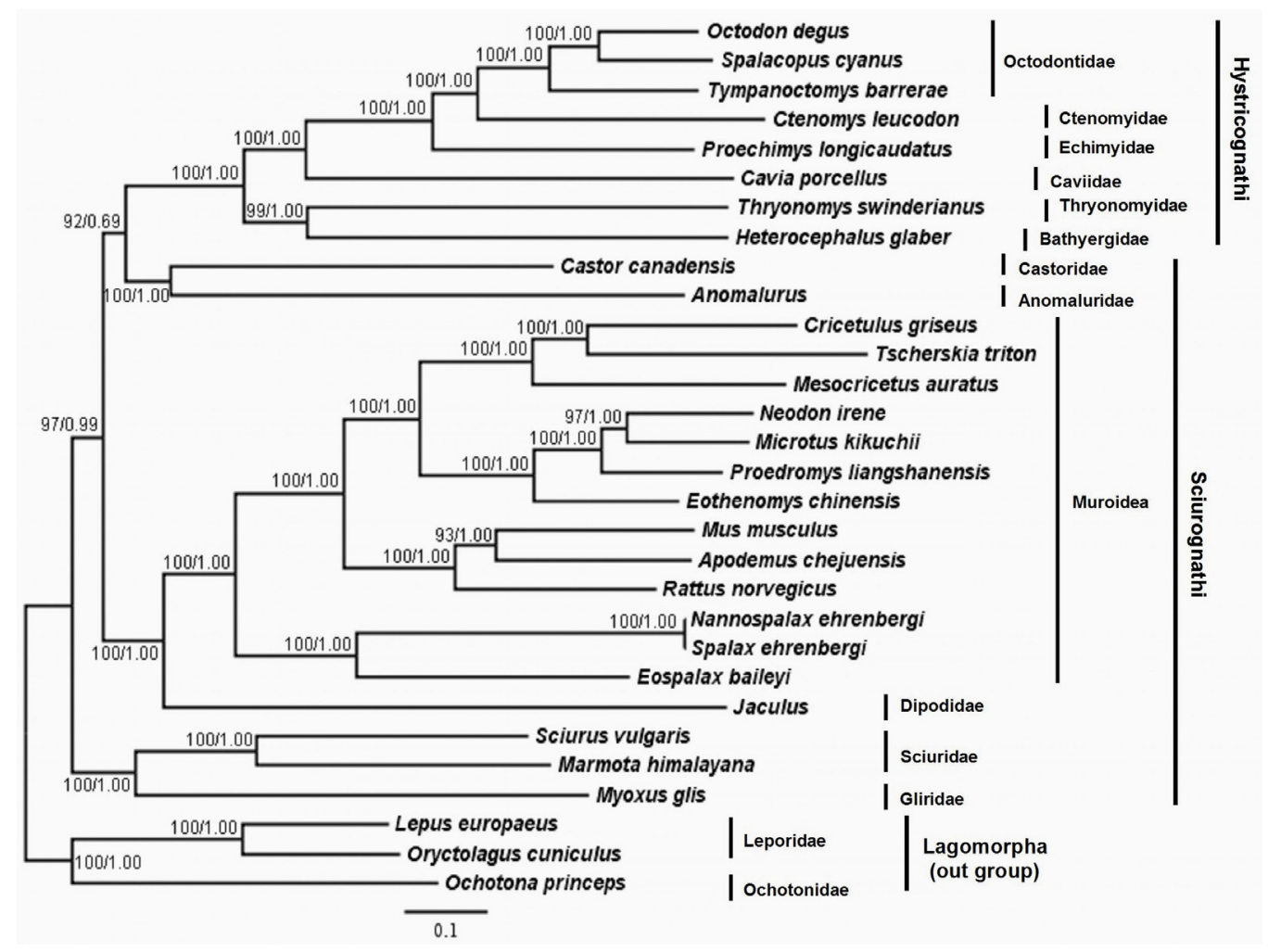

Figure 4. Phylogenetic tree obtained by the maximum-likelihood (ML) method and Bayesian analyses based on the nucleotide sequences of complete mitochondrial genome (without the control region). The first number at each node is the bootstrap probability of ML analyses and the second number is Bayesian posterior probability.

\section{DISCUSSION}

Here, we have determined the complete mitochondrial sequence of the marmot $M$. himalayana, and identified and characterized the sequences for the mitochondrial genes and the control region. In particular, we also used the $M$. himalayana $\mathrm{mt}$ genome sequence to analyze the phylogenetic relationships within Rodentia, including $M$. himalayana and 26 representative species with the three typical Lagomorpha taxa used as outgroup. Our data supported polyphyly of the Sciurognathi and monophyly of the Hystricognathi. As we expected, M. himalayana was found to be most closely related to taxa in the same genus (for example, S. vulgaris), followed by Gliridae (M. glis), regardless of the method used for phylogenetic reconstruction. The findings obtained in this study offer useful information for additional studies to gain a better understanding of the genetic content of the Rodentia and the commercially important marmota species. 


\section{ACKNOWLEDGMENTS}

Research supported by the National Natural Science Foundation of China (\#31260259), the Anhui Provincial Natural Science Foundation (\#1208085MC45), and the Natural Science Key Foundation (\#KJ2010A299) from the Department of Education of Anhui Province.

\section{REFERENCES}

Armitage KB (1975). Social behavior and population dynamics of marmots. Oikos 26: 341-354.

Armitage KB (1987). Social dynamics of mammals: Reproductive success, kinship and individual fitness. Trends Ecol. Evol. 2: 279-284.

Armitage KB (1999). Evolution of sociality in marmots. J. Mammal. 80: 1-10.

Arnold W (1990). The evolution of marmot sociality: II. Costs and benefits of joint hibernation. Behav. Ecol. Sociobiol. 27: 239-246.

Avis JC (1994). Molecular Markers, Natural History and Evolution. 2nd edn. Kluwer Academic Publishers, New York. Barash DP (1989). Marmots: Social Behavior and Ecology. 1st edn. Stanford University Press, Stanford Calif.

Benson G (1999). Tandem repeats finder: a program to analyze DNA sequences. Nucleic Acids Res. 27: 573-580.

Blumstein DT, Steinmetz J, Armitage KB and Daniel JC (1997). Alarm calling in yellow-bellied marmots: II: The importance of direct fitness. Anim. Behav. 53: 173-184.

Boore JL (1999). Animal mitochondrial genomes. Nucleic Acids Res. 27: 1767-1780.

Brown WM (1983). Evolution of Genes and Proteins. 3rd edn. Sunderland MA Press, Sinauer Association.

Castro JA, Picornell A and Ramon M (1998). Mitochondrial DNA: a tool for populational genetics studies. Int. Microbiol. 1: 327-332.

Cui P, Ji R, Ding F, Qi D, et al. (2007). A complete mitochondrial genome sequence of the wild two-humped camel (Camelus bactrianus ferus): an evolutionary history of camelidae. BMC Genomics 8: 241.

David SH, Konstantinos L, Reyes A, Carmela G, et al. (2007). Phylogenetic analyses of complete mitochondrial genome sequences suggest a basal divergence of the enigmatic rodent Anomalurus. BMC Evol. Biol. 7: 16.

Delisle I and Strobeck C (2002). Conserved primers for rapid sequencing of the complete mitochondrial genome from carnivores, applied to three species of bears. Mol. Biol. Evol. 19: 357-361.

Giles RE, Blanc H, Cann HM and Wallace DC (1980). Maternal inheritance of human mitochondrial DNA. Proc. Natl. Acad. Sci. U. S. A. 77: 6715-6719.

Hou WR, Chen Y, Wu X, Hu JC, et al. (2007). A complete mitochondrial genome sequence of Asian black bear Sichuan subspecies (Ursus thibetanus mupinensis). Int. J. Biol. Sci. 3: 85-90.

Hwang DS, Ki JS, Jeong DH, Kim BH, et al. (2008). A comprehensive analysis of three Asiatic black bear mitochondrial genomes (subspecies ussuricus, formosanus and mupinensis), with emphasis on the complete mtDNA sequence of Ursus thibetanus ussuricus (Ursidae). Mitochondrial DNA 19: 418-429.

Kjer KM and Honeycutt RL (2007). Site specific rates of mitochondrial genomes and the phylogeny of eutheria. $B M C$ Evol. Biol. 7: 8.

Kjer KM, Blahnik RJ and Holzenthal RW (2001). Phylogeny of Trichoptera (caddisflies): characterization of signal and noise within multiple datasets. Syst. Biol. 50: 781-816.

Lowe TM and Eddy SR (1997). tRNAscan-SE: a program for improved detection of transfer RNA genes in genomic sequence. Nucleic Acids Res. 25: 955-964.

Mathews DH, Sabina J, Zuker M and Turner DH (1999). Expanded sequence dependence of thermodynamic parameters improves prediction of RNA secondary structure. J. Mol. Biol. 288: 911-940.

Mathews DH, Disney MD, Childs JL, Schroeder SJ, et al. (2004). Incorporating chemical modification constraints into a dynamic programming algorithm for prediction of RNA secondary structure. Proc. Natl. Acad. Sci. U. S. A. 101: 7287-7292.

Miyata T, Hayashida H, Kikuno R, Hasegawa M, et al. (1982). Molecular clock of silent substitutions: at least a sixfold preponderance of silent changes in mitochondrial genes over those in nuclear genes. J. Mol. Evol. 19: 28-35.

Moritz C, Dowling TE and Brown WM (1987). Evolution of animal mtDNA: relevance for population biology and systematics. Annu Rev. Ecol. Syst. 18: 269-292.

Ojala D, Montoya J and Attardi G (1981). tRNA punctuation model of RNA processing in human mitochondria. Nature 290: 470-474.

Peng R, Zeng B, Meng X, Yue B, et al. (2007). The complete mitochondrial genome and phylogenetic analysis of the giant

Genetics and Molecular Research 13 (2): 2739-2751 (2014)

CFUNPEC-RP www.funpecrp.com.br 
panda (Ailuropoda melanoleuca). Gene 397: 76-83.

Reyes A, Pesole G and Saccome C (1998). Complete mitochondrial DNA sequence of the fast dormouse, Glis glis: further evidence of rodent paraphyly. Mol. Biol. Evol. 15: 499-505.

Reyes A, Gissi C, Pesole G, Catzeflis FM, et al. (2000). Where do rodents fit? Evidence from the complete mitochondrial genome of Sciurus vulgaris. Mol. Biol. Evol. 17: 979-983.

Reyes A, Gissi C, Catzeflis F, Nevo E, et al. (2004). Congruent mammalian trees from mitochondrial and nuclear genes using Bayesian methods. Mol. Biol. Evol. 21: 397-403.

Ronquist F and Huelsenbeck JP (2003). MrBayes 3: Bayesian phylogenetic inference under mixed models. Bioinformatics 19: $1572-1574$

Saccone C, De Giorgi C, Gissi C, Pesole G, et al. (1999). Evolutionary genomics in Metazoa: the mitochondrial DNA as a model system. Gene 238: 195-209.

Sbisa E, Tanzariello F, Reyes A, Pesole G, et al. (1997). Mammalian mitochondrial D-loop region structural analysis: identification of new conserved sequences and their functional and evolutionary implications. Gene 205: 125-140.

Shadel GS and Clayton DA (1993). Mitochondrial transcription initiation. Variation and conservation. J. Biol. Chem. 268: 16083-16086.

Stamatakis A (2006). RAxML-VI-HPC: maximum likelihood-based phylogenetic analyses with thousands of taxa and mixed models. Bioinformatics 22: 2688-2690.

Steppan SJ, Akhverdyan MR, Lyapunova EA, Fraser DG, et al. (1999). Molecular phylogeny of the marmots (Rodentia: Sciuridae): tests of evolutionary and biogeographic hypotheses. Syst. Biol. 48: 715-734.

Thompson JD, Gibson TJ, Plewniak F, Jeanmougin F, et al. (1997). The CLUSTAL_X windows interface: flexible strategies for multiple sequence alignment aided by quality analysis tools. Nucleic Acids Res. 25: 4876-4882.

Wolstenholme DR (1992). Mitochondrial Genomes. 2nd edn. Academic Press, New York.

Wyman SK, Jansen RK and Boore JL (2004). Automatic annotation of organellar genomes with DOGMA. Bioinformatics 20: 3252-3255.

Yamanoue Y, Miya M, Matsuura K, Yagishita N, et al. (2007). Phylogenetic position of tetraodontiform fishes within the higher teleosts: Bayesian inferences based on 44 whole mitochondrial genome sequences. Mol. Phylogenet. Evol. 45: 89-101.

Zhou Y, Zhang JY, Zheng RQ, Yu BG, et al. (2009). Complete nucleotide sequence and gene organization of the mitochondrial genome of Paa spinosa (Anura: Ranoidae). Gene 447: 86-96. 